\title{
Impact of gender on the decision to participate in a clinical trial: a cross-sectional study
}

\author{
Lucas Lobato ${ }^{1 *}$, Jeffrey Michael Bethony ${ }^{2}$, Fernanda Bicalho Pereira ${ }^{1}$, Shannon Lee Grahek ${ }^{2}$, David Diemert ${ }^{2}$ \\ and Maria Flávia Gazzinelli ${ }^{1}$
}

\begin{abstract}
Background: In order for Informed Consent to be ethical and valid each clinical trial participant must be able to make a voluntary decision to participate, free from pressure or coercion. Nonetheless, many factors may influence the decision reached, and such influences may be different for male and female volunteers. Being aware of these differences may help researches develop better processes for obtaining consent that safeguard the right of autonomy for all participants. The goal of this study was to evaluate potential gender-based differences in the factors influencing clinical trial participation.
\end{abstract}

Methods: This cross-sectional study was conducted in the Northeast region of Minas Gerais, Brazil, in October 2011. A structured questionnaire was administered to 143 volunteers (48 male, 95 female) screened for participation in a clinical study of an investigational functional food with potential anthelminthic properties. Answers regarding their decision to participate in the study were compared, by gender, using chi-square and Mann Whitney tests. Odds ratios (OR) was used to measure association.

Results: A majority of subjects (58\% of males, $59 \%$ of females) listed the desire to collaborate with the development of a product against parasitic worms as their main reason for participation. Females were significantly more likely to report a decision influenced by friends, family, or researchers (OR 3.14, 3.45, and 3.46 respectively, p < 0.005). Females were also significantly more likely to report a decision influenced by general altruistic considerations (OR 8.45, $\mathrm{p}<0.005$ ). There was no difference, by gender, in the report of decisions influenced by informational meetings, understanding of the disease, or the availability of medical treatments or exams. There was also no difference in knowledge of the rights of research participants.

Conclusion: Study results indicate that there is a strong difference between male and female participants regarding social influences on the decision to participate in clinical research. Further research into the impact this may have on autonomy is warranted.

Keywords: Autonomy, Bioethics, Clinical research, Gender, Informed consent, Social influence, Voluntariness

\section{Background}

Obtaining the informed consent (IC) of potential clinical trial participants is an essential element of ethical human subjects research [1]. A critical component of the IC process is to treat each research participant with dignity, and to protect and promote his or her autonomy. In Brazil, as in many other countries, IC is both an ethical procedure and a legal requirement [2]. IC and the

\footnotetext{
* Correspondence: dalukxz@gmail.com

${ }^{1}$ School of Nursing, Federal University of Minas Gerais, 190 Av. Alfredo

Balena, Room 508, Belo Horizonte, MG 30130-100, Brazil

Full list of author information is available at the end of the article
}

procedures for obtaining IC are captured in legal, philosophical, institutional, and medical literature as a set of key elements - Information, Comprehension, Voluntariness, Competence, and Decision. IC is valid only if obtained through a process that ensures that all of the key elements are addressed [3]. Of these elements, voluntariness in particular has been of increasing interest to researchers. Voluntariness is the right of potential participants to make their own decisions, free from harassment or coercion that might lead them to act against their best interests [4]. Voluntariness may be impeded or empowered by external influences, including the social influence of 
family, friends, and the community, as well as the level of knowledge regarding participant rights, and access to health services or medical treatments provided through participation in a clinical trial that are not otherwise available $[5,6]$.

Additional research is needed to better understand the external influences on taking voluntary decisions to participate in clinical trials, as well as the groups that are more or less likely to experience these influences, and what steps may be taken in the informed consent process to minimize coercive influences and maximize autonomous decision making. Of particular concern in some clinical trial settings are patriarchal family structures that may result in gender-specific decision-making processes, with female participants under pressure to please male family leaders $[7,8]$.

The concept of gender encompasses the structure of social relationships institutionalized in a society, as well as individual relationships between males and females, their commonly accepted roles in society, and their everyday habits [9]. Therefore, a great deal of what is understood as masculine and feminine - with accompanying roles, representations, and responsibilities - goes through a construction process that is essentially social $[10,11]$. Concepts of differential gender roles are imparted and sustained through education and informal means [12]. Socially constructed gender roles are often considered attributes of femininity and masculinity and upheld in societies as natural or biological differences [13,14]. In this context gender roles determine the social expectations of each individual - what to think, how to act, what to wear, and what the individual's relationship to him or herself and to someone else should be $[9,15]$.

Based on this background, the hypothesis of this study is that the decision to participate in a clinical trial may differ by gender due to preexisting social influences on the decision-making process. There are socio-behavioral arguments, particularly relevant to clinical trials in Brazil, which support this hypothesis. Historically, many families in rural communities in Brazil have been structured with significant gender inequality and male dominance over the behavior of female family members [16,17]. Such organization is molded after a patriarchal system that governs all aspects of collective and individual activities, and includes role differentiation and hierarchy between sexes [18]. Therefore, the family structure revolves around male supremacy, valuing male-dominated activities at the expense of female-dominated ones, and legitimizing male control over the female body, sexuality, and autonomy [19].

Previous studies have examined the factors influencing the decision of individuals in these communities to participate in clinical trials, as well as levels of knowledge about the rights of research subjects [5,20]; however, these studies have not investigate whether the influencing factors affect male and female participants equally. Therefore, we conducted a study of the quality of the IC process for a clinical study of a novel functional food in a rural region of Northeastern Minas Gerais, Brazil, in the context potential gender differences. This study is of importance due to a rapid increase in the number of clinical trials being conducted in Brazil, as well as in other developing countries with similar gender-differentiated social structures $[21,22]$. The majority of what is known in Brazil on the topic of IC is in the context of hospitalbased clinical trials [23,24], and although voluntariness is considered one of the key elements of obtaining an ethical and valid IC, most IC studies focus on information comprehension [25,26]. There is little Brazilian or international literature dedicated to studying the voluntariness to participate in clinical trials, or that has investigated differences in the willingness to participate that are based on gender differences and voluntariness [27-30]. Therefore, the primary objective of this study was to determine if external factors influenced the decision to participate in clinical trials and whether these varied by gender. In keeping with Brazilian Resolution 196/96 [2], this study may also provide information to build practical strategies to strengthen the autonomy of all research participants.

\section{Methods}

\section{Study design and population}

Across-sectional, descriptive and quantitative questionnaire was administered to willing individuals who were consented to participate in a clinical study entitled " $A$ Double-blind, Randomized, Controlled Evaluation of the Tolerability of a Proprietary Oil Blend in Adults Residing in Areas Endemic for Helminth Infections" (Clinicaltrials. gov number NCT01271049), the primary objective of which was to evaluate the tolerability of a functional food with potential anthelminthic qualities among adults residing in an area of Brazil endemic for intestinal helminth infections. The clinical study took place in the district of Novo Oriente de Minas in the northeastern region of Minas Gerais, Brazil, between October 2011 and March 2012. Written informed consent was obtained from all volunteers who were willing to be screened for participation in the study. The Informed Consent Form (ICF) was read to each participant, or if the subject was literate, staff and the participant read the ICF together. After obtaining IC, participants were asked to complete a structured questionnaire to evaluate factors influencing their decision to participate in the clinical study.

One hundred and sixty-nine volunteers were screened for participation in the clinical study, and all agreed to complete the questionnaire. Due to a delay between obtaining consent and the administration of questionnaire 
(approximately one month), only 143 of 169 originally consented participants completed the questionnaire substudy. The reasons cited for non-participation following original consent were anticipated or actual change of residence to a different municipality (15) and the withdrawal of consent (11).

Study approval was received from the ethical review committees of the George Washington University, the René Rachou Research Center, and the Federal University of Minas Gerais.

\section{Data collection and statistical analysis}

Data for this sub-study were collected via a structured questionnaire designed to evaluate the voluntariness of the decision to participate in the clinical study and the participants' understanding of clinical research. In order to assess voluntariness, the questionnaire addressed possible factors influencing the decision to participate in the study, the primary reason for participating, and the level of knowledge about the rights of research participants. Questions were developed with guidance from other questionnaires used for similar purposes [31,32], the requirements of Resolution 196/96 of the National Health Council of Brazil on human subjects research [2], and international standards (such as the International Conference on Harmonisation). Questions were formatted as dichotomous "yes" or "no" questions.

Questionnaires required 10 minutes on average for completion, and were administered in an interview format in the residence of the participant. Interviewers were trained to standardize the information collection process in order to maximize reliability of the data and minimize bias. Following collection the data were coded and entered into an SPSS database (Version 14.0. Chicago, SPSS Inc.). Error was reduced through independent double data entry. In the case of discrepancies, the data in question were confirmed by review of the original questionnaire.

Data were described by absolute frequency, while quantitative variables were summarized by arithmetic means and standard deviations. Differences in socioeconomic, demographic, and motivation factors were compared by gender using the chi-square test for categorical data and the independent t-test for quantitative variables. Odds ratios (OR) and associated 95\% confidence intervals were used to estimate associations, and the chi-square test used to verify the significance of associations.

To analyze the combined influence of all factors on the decision to participate in a clinical study an index called the General Influence Index was created. Each factor marked as influential to a participant's decision received a score of 1 , and each factor marked as not influential received a score of 0 . Eight factors of influence were assessed for each participant, resulting in total scores ranging from 0 to 8 . Higher scores indicated greater influence by the evaluated factors and lower values lower influence. At the extremes, a total score of 0 indicated that the participant was not influenced by any factors evaluated in the questionnaire, whereas a total score of 8 indicated that the participant was influenced by all factors evaluated. Differences in the General Influence Index for male and female participants were compared using the Mann-Whitney test. P values of less than $5 \%$ were considered statistically significant.

\section{Results}

A total of 143 subjects completed the questionnaire, corresponding to $85 \%$ of the total number of volunteers who were approached. Participants were 34 years old on average, with a majority self-reporting as black or of mixed race. A majority of participants were also female, married, illiterate or had less than an $8^{\text {th }}$ grade education, had a family income of over BRL 545 (USD 247), and accessed electronic media more than five times per week. There were no statistically significant differences in demographics or socioeconomic status by gender (Table 1 ) or age ( $\mathrm{t}$-test; $\mathrm{p}=0.32$ ). There was also no significant difference in the sub-study population and the community from which volunteers were recruited in terms of age, race, gender, marital status, formal schooling, monthly income, and residence location (chi-square test and Mann Whitnney test; $\mathrm{p}>0.05$ for all statistical tests).

A majority of participants cited collaborating in the development of a product against parasitic worms (i.e., the aim of the clinical study) as a motivation for participating in the clinical trial $(58.0 \%$ and $59.5 \%$ for male and female participants, respectively). The potential of overcoming difficulties in accessing medical care was cited by $39.8 \%$ of male participants and $35.7 \%$ of female participants as being a motivating factor for study participation. A small minority of subjects in both gender groups (2.9\% and 5.3\% for males and females, respectively) indicated the desire to please researchers as a reason to participate in the study (Figure 1). Differences in factors motivating participation between gender groups were not statistically significant (chi-square; $\mathrm{p}=0.67$ ).

In regard to the rights of study participants, both male and female participants were most knowledgeable of the right to withdraw from the clinical trial at any time. Participants also displayed an understanding of the availability of medical treatment that was available outside of participation in the clinical study (e.g., at the municipal health clinic). Knowledge of these rights did not significantly differ by gender $(p=0.46)$. Both genders showed low knowledge of the right to continued medical treatment to which they are otherwise entitled in the case of withdrawal of consent, with no significant difference by gender $(\mathrm{p}=0.82)$ (Table 2$)$. 
Table 1 Socio-demographic and economic status $(n=143)$

\begin{tabular}{|c|c|c|c|c|}
\hline Variable & Male & Female & $x^{2}$ & $p$ \\
\hline \multicolumn{5}{|l|}{ Education level } \\
\hline - Elementary school & $31(21.7 \%)$ & $64(44.8 \%)$ & \multirow{2}{*}{0.11} & \multirow{2}{*}{0.7} \\
\hline - High school & $17(11.8 \%)$ & $31(21.7 \%)$ & & \\
\hline \multicolumn{5}{|l|}{ Family income } \\
\hline - Below R\$545 & $22(15.4 \%)$ & $50(34.9 \%)$ & \multirow{2}{*}{0.59} & \multirow{2}{*}{$0.4 \varepsilon$} \\
\hline - Above to $R \$ 545$ & $26(18.3 \%)$ & $45(31.4 \%)$ & & \\
\hline \multicolumn{5}{|l|}{ Marital status } \\
\hline - Single & $11(7.6 \%)$ & $18(12.6 \%)$ & \multirow{2}{*}{0.31} & \multirow{2}{*}{0.57} \\
\hline - Married & $37(25.9 \%)$ & $77(53.9 \%)$ & & \\
\hline \multicolumn{5}{|c|}{ Access to electronic media (per week) } \\
\hline - 2 to 4 times & $17(11.8 \%)$ & $24(16.7 \%)$ & \multirow{2}{*}{0.97} & \multirow{2}{*}{$0.4 C$} \\
\hline - 5 to 7 times & $31(21.8 \%)$ & $71(49.7 \%)$ & & \\
\hline Total & $48(27.7 \%)$ & $95(72.3 \%)$ & - & - \\
\hline
\end{tabular}

In the General Influence Index, female participants scored an average of 6.2 (SD: 1.76) with a median of 7.0, and male participants an average of 5.0 (SD: 1.97), median of 5.0 ( $\mathrm{Z}=-3.61$. $\mathrm{U}=1449.5 ; \mathrm{p}=0.02)$. Both gender groups included participants with minimum scores of 0 (no influence) and maximum scores 8 (influenced by all factors evaluated). Figure 2 shows a boxplot of the General Influence Index, by gender.

Female participants were significantly more likely than male participants to report a decision influenced by friends, family, the researcher and the altruism (OR: 3.14, $3.45,3.46$ and 8.45 , respectively, $\mathrm{p}<0.005$ in statistical tests), while no decision-influencing factors were significantly more likely among male participants (Table 3 ).

\section{Discussion}

The results of this study indicate that male and female participants differed in the factors that influenced their decision to participate in the ABS-00-02 clinical trial.
Most importantly, female participants were more likely than male participants to have their decision to participate influenced by their partner or their families. These results support the theory that the decision to participate in clinical research may be impacted not only by the individual characteristics of participants, but also by interpersonal relationships and social norms of the community where the study is conducted [33]. A similar pattern was found in a study conducted in Ghana, where all interviewed female participants indicated that they consulted their husbands before deciding to participate. Of these, some indicated that if their husband had been against their participation they would have declined, whereas others indicated that the final decision was their own to make [34]. In another study in Ghana, it was observed that the decision of female volunteers to participate was frequently subject to the control of a parent or husband [35].

It is hypothesized that the influence of a partner or family member is greater in clinical trials taking place in

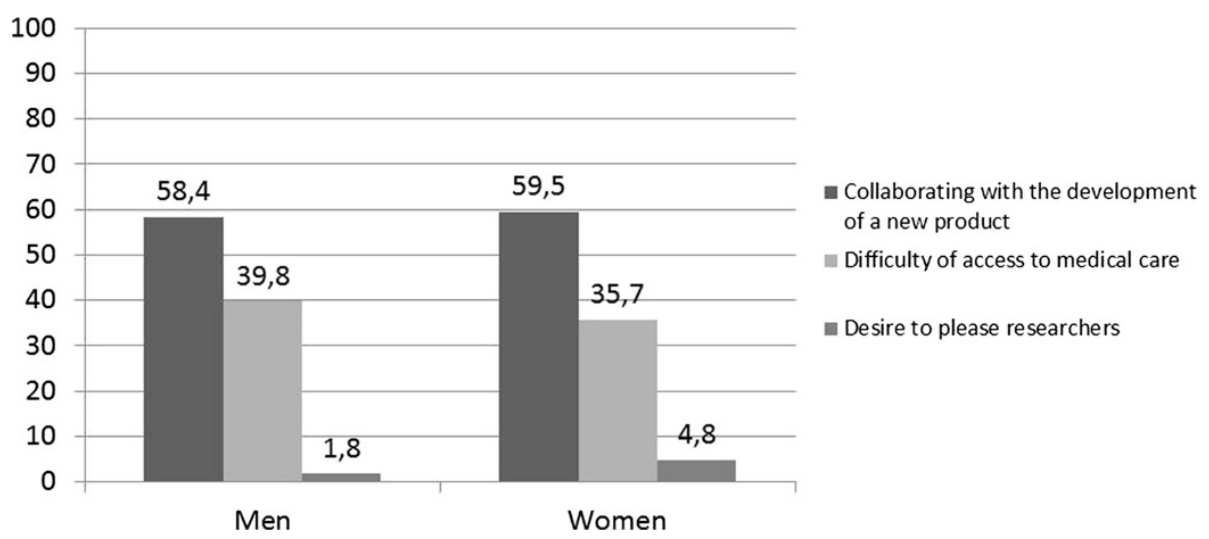

Figure 1 The lines represents the percentage of responses of the reasons for participation in the clinical trial ABS-00-02. 
Table 2 Knowledge about the rights of the clinical trial participant ABS-00-02, according to the genre

\begin{tabular}{|c|c|c|c|c|c|c|}
\hline \multirow[t]{2}{*}{ Question } & Male & Female & \multirow{2}{*}{$x^{2}$} & \multirow{2}{*}{$\mathbf{p}$} & \multirow{2}{*}{ OR } & \multirow{2}{*}{$\mathrm{Cl}(95 \%)$} \\
\hline & \multicolumn{2}{|c|}{ n (\%) } & & & & \\
\hline Alternative of medical treatment & $39(81,1 \%)$ & $71(74,4 \%)$ & 0,54 & 0,45 & 0,72 & $0,30-1,71$ \\
\hline Withdraw from the research & $44(91,6 \%)$ & $86(90,5 \%)$ & 0,56 & 0,82 & 0,86 & $0,25-2,98$ \\
\hline Maintenance of medical treatment in case of leaving the study & $14(29,1 \%)$ & $22(23,1 \%)$ & 0,48 & 0,54 & 0,77 & $0,35-1,69$ \\
\hline
\end{tabular}

Statistical test for Chi-Square; Odds Ratio; Confidence Interval (95\%).

Americaninhas, Minas Gerais, $2011(n=143)$

developing countries than in developed countries. This is supported by the results of a multicenter study of hypertension and genetics, in which no female participants enrolled in the US solicited the advice of a partner before participation, compared to $47 \%$ of female participants enrolled in Nigeria that solicited the advice of their partner prior to participating in the trial [7]. Despite this, social influencers have also been observed in studies based in developed countries, including a health services study conducted in the UK enrolling 32 pregnant women, of which 9 delegated their decision to be tested for HIV to another person, including a partner, close friend, or health professional. Of these, 3 reported feeling pressure to consent to the test against their wish, due to external influence [35].

Taken together, these studies indicate that the need or desire to solicit advice from domestic partners or other family members as part of the decision making process may be greater for female participants in developing country settings, but is likely to be observed to varying degrees across settings. Although undue pressure by a partner or family member to participate or not participate in clinical research is an impediment to autonomy, consultation in itself may not be an impediment, and may in fact lead to greater contemplation and a more informed decision. Additional research is needed to understand the extent to which the differences in social influence seen in this study relate to undue pressure or coercion, or a difference in personal preference to seek consultation with others prior to reaching an independent decision.

Although low for both groups, another important finding of this study was the difference, by gender, in the reported influence of researchers on the decision to participate. It is thought that in Americaninhas, the site

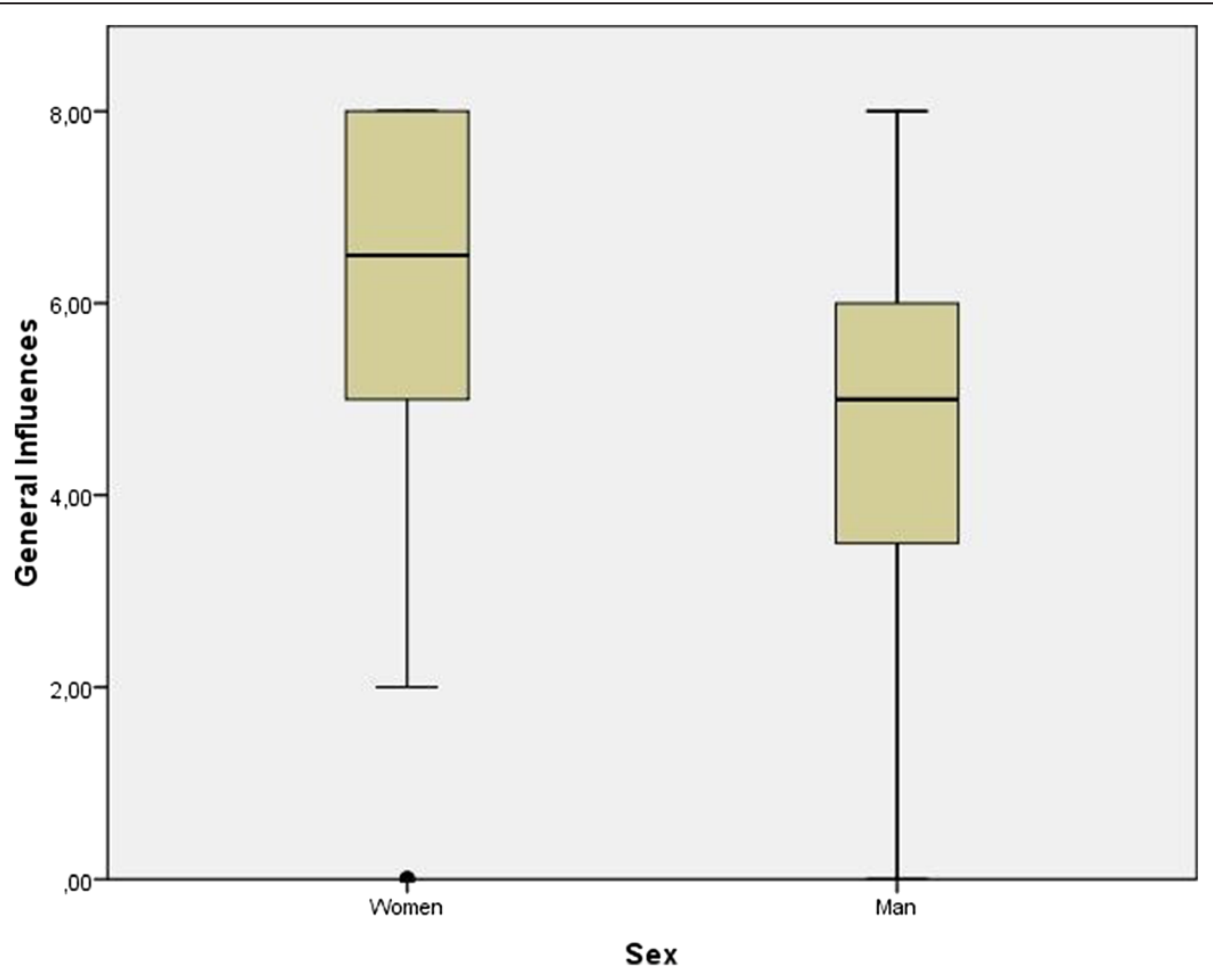

Figure 2 General Influences represents the sum of influences that the participants of indicated when choosing to participate in the clinical trial (Eight types of influence evaluated by the study). The figure shows a comparison of the general Influence according to the sex of trial participants. 
Table 3 Influential factors in the decision of trial participants ABS-00-02 according to gender

\begin{tabular}{|c|c|c|c|c|c|c|}
\hline Variables & Female & Male & $x^{2}$ & $p$ & OR & IC (95\%) \\
\hline \multicolumn{7}{|l|}{ Friends } \\
\hline Influenced & $43(45,3 \%)$ & $10(20,8 \%)$ & \multirow{2}{*}{8,15} & \multirow{2}{*}{0,006} & \multirow{2}{*}{3,14} & \multirow{2}{*}{$1,45-7,03$} \\
\hline Not influenced & $52(54,7 \%)$ & $38(79,2 \%)$ & & & & \\
\hline \multicolumn{7}{|l|}{ Family (Spouse) } \\
\hline Influenced & $58(61,1 \%)$ & $15(26,7 \%)$ & \multirow{2}{*}{11,33} & \multirow{2}{*}{0,001} & \multirow{2}{*}{3,44} & \multirow{2}{*}{$1,65-7,20$} \\
\hline Not influenced & $37(38,9 \%)$ & $33(73,3 \%)$ & & & & \\
\hline \multicolumn{7}{|l|}{ Researcher } \\
\hline Influenced & $83(91,7 \%)$ & $32(66,7 \%)$ & \multirow{2}{*}{8,67} & \multirow{2}{*}{0,001} & \multirow{2}{*}{3,45} & \multirow{2}{*}{$1,47-8,11$} \\
\hline Not influenced & $12(8,3 \%)$ & $16(33,3 \%)$ & & & & \\
\hline \multicolumn{7}{|l|}{ Meetings } \\
\hline Influenced & $75(78,9 \%)$ & $33(68,8 \%)$ & \multirow{2}{*}{1,79} & \multirow{2}{*}{0,18} & \multirow{2}{*}{1,70} & \multirow{2}{*}{$0,78-3,70$} \\
\hline Not influenced & $20(21,1 \%)$ & $15(31,2 \%)$ & & & & \\
\hline \multicolumn{7}{|c|}{ Learning about the disease } \\
\hline Influenced & $74(85,4 \%)$ & $34(70,9 \%)$ & \multirow{2}{*}{0,86} & \multirow{2}{*}{0,35} & \multirow{2}{*}{1,45} & \multirow{2}{*}{$0,65-3,19$} \\
\hline Not influenced & $21(14,6 \%)$ & $14(29,1 \%)$ & & & & \\
\hline \multicolumn{7}{|c|}{ Helping others (altruism) } \\
\hline Influenced & $91(95,7 \%)$ & $35(72,9 \%)$ & \multirow{2}{*}{15,92} & \multirow{2}{*}{0,01} & \multirow{2}{*}{8,45} & \multirow{2}{*}{$2,58-27,67$} \\
\hline Not influenced & $4(4,3 \%)$ & $13(27,1 \%)$ & & & & \\
\hline \multicolumn{7}{|c|}{ Medical treatment } \\
\hline Influenced & $80(84,3 \%)$ & $41(85,5 \%)$ & \multirow{2}{*}{0,03} & \multirow{2}{*}{0,82} & ( 01 & 02 \\
\hline Not influenced & $15(15,7 \%)$ & $7(14,5 \%)$ & & & 0,91 & $0,34-2,40$ \\
\hline Medical exams & & & & & & \\
\hline Influenced & $85(89,4 \%)$ & $40(83,4 \%)$ & & & & \\
\hline Not influenced & $10(10,6 \%)$ & $8(16,6 \%)$ & 1,09 & 0,29 & 1,68 & $0,06-4,00$ \\
\hline Total & $95(72,3 \%)$ & $48(27,7 \%)$ & - & - & - & - \\
\hline
\end{tabular}

Statistical test for Chi-Square; Odds Ratio; Confidence Interval (95\%).

Americaninhas, Minas Gerais, $2011(\mathrm{n}=143)$.

of the ABS-00-02 study, this researcher influence is comparable to the influence of health professionals on patient decisions in hospital environments. This interpretation is supported by studies conducted in the same region, which found that participants considered study researchers as equivalent to standard care medical doctors [5,31]. A number of studies have also indicated that in certain settings male health-seeking behavior may be lower as compared to female health-seeking behavior for a number of reasons, including a perceived weakness or vulnerability in requiring medical assistance $[36,37]$. The non-differentiation of researchers from standard care doctors combined with differing health-seeking behaviors may therefore explain the difference in the influence of researchers, by gender, on the decision to participate in the ABS-00-02 clinical trial.

This study also examined motivating factors for voluntary participation, and may provide insight into the question raised by Diniz [37] in an bioethics related article, where he asked "... what would cause someone to voluntarily put themselves at risk when there are no financial advantages?" This question is especially pertinent in countries such as Brazil, where offering financial incentives for participation in clinical research is prohibited [2]. Diniz cites a lack of access to medical treatment as the answer to this question, while our response is that there may be many motivating factors in addition to, or in place of, financial incentives. In this study, a high percentage of ABS-00-02 participants did indicate that access to health services was a motivating factor for participation, and lack of access to medical treatment is commonly cited across a number of settings, including in studies conducted in African in response to the HIV/AIDS epidemic [38]. Alternative answers relating to the idea of voluntariness are for the benefit to ones own family or community, and for the benefit to society at large (general altruism). In this study, the desire to collaborate in the development of a product capable of fighting hookworm disease, highly endemic in the region, was cited as a motivating factor for participation in the ABS-00-02 trial by a majority of 
participants, both male and female. In another clinical trial conducted in Brazil, and in trials conducted in African, the Caribbean, the US, and Australia, general altruism was reported as a major motivating factor for participation $[5,39,40]$.That said, for the ABS-00-02 study, only a small minor of participants reported general altruism as a motivating factor in their decision to participate in the trial.

Although cited as a challenge to IC in developing countries, nearly all participants in this study understood the right to withdraw from the study at any time. Unfortunately, a lack of knowledge regarding alternatives to participation may compel subjects to continue in studies despite knowledge of the right of withdraw $[41,42]$. Therefore, knowledge regarding the right to withdraw from research must be linked with an understanding of alternatives to participation, including the right to not participate without loss of medical treatment or care to which one is otherwise entitled $[38,43,44]$. In this study a majority of participants correctly cited the availability of alternative medical treatments. Awareness of medical alternatives may be due in part to the fact that residents of Americaninhas have easy access to parasitological exams and chemotherapy treatment in the Unidade Básica de Saúde (Basic Health Unit), offered by the Sistema Único de Saúde (Unified Public Health System) free of charge, as well as access to additional exams and anthelmintic chemotherapy through the primary care network of the Novo Oriente de Minas municipality. Given this, it is not known if the observed high rate of understanding of alternatives to participation would carry-over to another trial for an indication not well understood by this study population, or not addressed in the local health system. This is in fact an area of great ethical debate. In a study in Ghana a majority of participants cited participation as the only method to obtain a medication for the treatment of HIV/AIDS, and in some cases mistook research with medical treatment. This confusion may stem from the fact that a number of studies conducted in the study area included access to basic medical care not otherwise readily accessible to the population [42].

A possible limitation of this study is non-differential recall bias due to the 1-month lag between volunteers making a decision to participate in the clinical trial and administration of the sub-study questionnaire. Intentional responder bias is also possible if volunteers perceived a particular response to be more desirable. The potential for these biases was minimized by a relatively short 1-month lag time between clinical trial consent and questionnaire administration, the use of simple closed-end questions, administration of the questionnaire in a standardized fashion by trained interviewers, and exclusion of highly sensitive or culturally taboo topics.

\section{Conclusion}

In certain settings female participants appear to be more likely than male participants to solicit the advice of domestic partners or family members prior to providing consent to participate in clinical trials. Even where the informed consent process meets national and international standards if such consultation includes undue pressure the right to autonomy will be impacted $[45,46]$. Given this, some have asserted that in settings of ingrained gender inequality, where such undue pressure or coercion is likely, female study participants should in fact be considered extrinsically vulnerable $[47,48]$. We believe that acknowledgment and examination of differences in social influence on the decision-making process is an important step to improving informed consent processes and obtaining valid IC $[49,50]$. In settings where autonomy may otherwise be compromised additional strategies to promote IC should be considered, such as educational interventions prior to study recruitment $[5,20,24]$. However, in all settings such efforts should not extend to exclusion of females from research studies [38]. Not only would such exclusion negatively impact the study of exclusively female conditions, it would deprive women of the many potential benefits of research participation [51,52].

Additional evaluation of gender differences on the decision to voluntarily participate in clinical research is thus warranted, particularly to examine the degree to which differences in social influence relate to undue control over or decreased autonomy of female participants versus individual preference for external consultation or decision-making support. Additional research to assess the perception of voluntariness using validated instruments such as the Decision Making Control Instrument is also encouraged [53].

\section{Competing interests}

The authors declare that they have no competing interests.

\section{Authors' contributions}

LL contributed to concept development, questionnaire design, data collection, data analysis and interpretation, manuscript preparation, and manuscript finalization. JMB contributed to data analysis and interpretation, manuscript preparation, and manuscript finalization. FBP contributed to concept development, data analysis and interpretation, manuscript preparation, and manuscript finalization. DD contributed to data analysis and interpretation, manuscript preparation, and manuscript finalization. SLG contributed to data analysis and interpretation, manuscript preparation, and manuscript finalization. All authors confirm that this manuscript has not been previously published and is not being considered for publication in any other journal. All authors read and approved the final manuscript.

\section{Acknowledgments}

We wish to thank all who participated directly or indirectly in this research. The study population was drawn from a clinical trial sponsored and funded by Kraft Foods, Inc. 


\section{Author details}

'School of Nursing, Federal University of Minas Gerais, 190 Av. Alfredo Balena, Room 508, Belo Horizonte, MG 30130-100, Brazil. ²Department of Microbiology, Immunology and Tropical Medicine, School of Medicine and Health Sciences, The George Washington University, Washington, DC, USA.

Received: 9 August 2013 Accepted: 28 October 2014

Published: 6 November 2014

\section{References}

1. Emanuel EJ, Wendler D, Killen J, Grady C: What makes clinical research in developing countries ethical? The benchmarks of ethical research. $J$ Infect Dis 2004, 189:930-937.

2. Conselho Nacional de Saúde: Resolução nº 196 de 10 de outubro de 1996. Brasília (DF): Diretrizes e normas regulamentadoras de pesquisas envolvendo seres humanos [online]. Diário Oficial da República Federativa do Brasil; 1996. Disponível em: http://conselho.saude.gov.br/docs/Reso196.do.

3. Beauchamp TL, Childress JF: Principles of Biomedical Ethics. 5th edition. New York: Oxford University Press; 2001.

4. Raymundo MM, Goldim JR: Do consentimento por procuração à autorização por representação. Revista Bioética 2007, 15:83-99.

5. Almeida CH, Marques RC, Reis DC, Couto-Melo JM, Diemert DJ, Gazzinelli MF: A pesquisa científica na saúde: uma análise sobre a participação de populações vulneráveis. Texto Contexto - Enfermagen 2010, 19:104-111.

6. Mandava A, Pace C, Campbell B, Emanuel E, Grady C: The quality of informed consent: mapping the landscape. A review of empirical data from developing and developed countries. J Med Ethics 2012, 38:356-365.

7. Marshall PA, Adebamowo CA, Adeyemo AA, Ogundiran TO, Vekich M, Strenki T, Zhou J, Prewitt E, Cooper RS, Rotimi CN: Voluntary participation and informed consent to international genetic research. Am J Public Health 2006, 96:1989-1995.

8. Tekola F, Bull SJ, Farsides B, Newport MJ, Adeyemo A, Rotimi CN, Davey G: Tailoring consent to context: designing an appropriate consent process for a biomedical study in a low income setting. PLoS Negl Trop Dis 2009, 3:e482.

9. Arrazola LSD: O cotidiano sexuado de meninos e meninas em situação de pobreza. In Quem mandou nascer mulher?. Edited by Madeira FR. Rio de Janeiro: Record/Rosa dos tempos; 1997:347-402.

10. Welzer-Lang D: Os homens e o masculino numa perspectiva de relações sociais de sexo. Em: M.R. Schpun (org.). Masculinidades. São Paulo: Boitempo; Santa Cruz do Sul: Edunisc; 2004:107-128.

11. Kimmel MS: A produção simultânea de masculinidades hegemônicas e subalternas. (O.F. Leal, trad.). Porto Alegre: Horizontes Antropológicos; 1998:103-117.

12. Meyer DE: Gênero e educação: teoria e política. In Corpo, gênero e sexualidade: um debate contemporâneo na educação. Edited by Louro GL, Nekel JF, Goellner SV. Petrópolis, RJ: Vozes; 2003:9-27.

13. Trindade ZA, Nascimento ARA, Gianordoli-nascimento IF: Violência, exclusão social e desenvolvimento humano. Estudos em representações sociais. 3rd edition. Brasilia: Universidade de Brasília; 2006.

14. Torrão Filho A: Uma questão de gênero: onde o masculino e o feminino se cruzam. Cadernos Pagu 2005, 24:127-152.

15. Cosa LHR, Coelho EAC: Ideologias de gênero e sexualidade: a interface entre a educação familiar e a formação profissional de enfermeiras. Texto Contexto Enferm 2013, 22:485-492.

16. Ressel LB, Gualda DM: Sexuality as cultural construction: reflections on inherent prejudice and myths in a group of rural women. Rev Esc Enferm USP 2003, 37:82-87.

17. Rocha-Coutinho ML: Dos contos de fada aos super-heróis: mulheres e homens brasileiros reconfiguram identidades. Psicologia Clínica 2000, 2:65-82.

18. Hirata $\mathrm{H}$, Laborie F, Le Doaré $\mathrm{H}$, Senotier D: Dicionário de Feminismo. $3^{\circ}$ th edition. São Paulo: Editora UNESP; 2009

19. Narvaz MG, Koller SH: Famílias e patriarcado: da prescrição normativa à subversãocriativa. Psicol Soc 2006, 18:49-55.

20. Lobato L, Souza V, Caçador B, Soares A, Wingester E, Gazzinelli M: Efeitos de intervenção educativa na qualidade ética do consentimento livre e esclarecido. Revista Bioética 2012, 20:479-489.

21. deZulueta P, Boulton M: Routine antenatal HIV testing: the responses and perceptions of pregnant women and the viability of informed consent. A qualitative study. J Med Ethics 2007, 33:329-336.
22. Thiers FA, Sinskey AJ, Berndt ER: Trends in the globalization of clinical trials. Nat Rev Drug Discov 2008, 7:13-14.

23. Cheng JD, Hitt J, Koczwara B, Schulman KA, Burnett CB, Gaskin DJ, Rowland $J \mathrm{H}$, Meropol NJ: Impact of quality of life on patient expectations regarding phase I clinical trials. J Clin Oncol 2000, 18:421-428.

24. Araujo DVP, Zoboli ELCP, Massad E: Como tornar os termos de consentimento mais fáceis de ler? Rev Assoc Med Bras 2010, 56:151-156.

25. Muthuswamy V: Ethical issues in HIV/AIDS research. Indian J Med Res 2005, 121:601-610.

26. Kaewpoonsri N, Okanurak K, Kitayaporn D, Kaewkungwal J, Vijaykadga S, Thamaree S: Factors related to volunteer comprehension of informed consent for a clinical trial. Southeast Asian I Trop Med Public Health 2006, 37:996-1004.

27. Valapour M, Kahn JP, Bailey RF, Matas AJ: Assessing elements of informed consent among living donors. Clin Transplant 2011, 25:185-190.

28. Behrendt C, Gölz T, Roesler C, Bertz H, Wünsch A: What do our patients understand about their trial participation? Assessing patients understanding of their informed consent consultation about randomised clinical trials. J Med Ethics 2011, 37:74-80.

29. Minnies D, Hawkridge T, Hanekom W, Ehrlich R, London L, Hussey G Evaluation of the quality of informed consent in a vaccine field trial in a developing country setting. BMC Med Ethics 2008, 9:1-9.

30. Horwitz RH, Roberts LW, Seal DW, Joseph P, Maschke KJ, Verdier Rl, Nerette S, Pape JW, Fitzgerald DW: Assessing whether consent for a clinical trial is voluntary. Ann Intern Med 2013, 158:222-224.

31. Meneguin S, Zoboli ELCP, Domingues RZL, Nobre MR, Cesar LAM: Entendimento do termo de consentimentoporpacientespartícipe sempesquisascomfármaconacardiologia. Ara Bras Cardiol 2010, 94:4-9.

32. Gazzinelli MF, Lobato L, Matoso L, Avila R, de Cassia Marques R, Shah Brown A, Correa-Oliveira R, Bethony JM, Diemert DJ: Health education through analogies: preparation of a community for clinical trials of a vaccine against hookworm in an endemic area of Brazil. PLoS Negl Trop Dis 2010, 4:e749.

33. Gazzinelli MF, Souza V, Lobato L, Nathale A: Teatro na educação de crianças e adolescentes. Rev Saude Publica 2012, 46(6):999-1006.

34. Bajotto AP, Goldim JR: Consentimento informado: cuidado para o recrutamento de populações vulneráveis. Revista Bioética 2012, 20:226-231.

35. Mystakidou K, Panagiotou I, Katsaragakis S, Tsilika E, Parpa E: Ethical and practical challenges in implementing informed consent in HIV/AIDS clinical trials in developing or resource-limited countries. SAHARA J 2009, 6:46-57.

36. Guerriero I, Ayres JR, Hearst N: Masculinity and vulnerability to HIV among heterosexual men in Sao Paulo, Brazil. Rev Saude Publica 2002, 36:50-60.

37. Diniz D: Bioética e gênero. Revista Bioética 2008, 16(2):207-216.

38. Dawson L, Kass NE: Views of US researchers about informed consent in international collaborative research. Soc Sci Med 2005, 61:1211-1222.

39. Rosenbaum JR, Wells CK, Viscoli CM, Brass LM, Kernan WN, Horwitz Rl: Altruism as a reason for participation in clinical trials was independently associated with adherence. J Clin Epidemiol 2005, 58:1109-1114.

40. Krosin MT, Klitzman R, Levin B, Cheng J, Ranney ML: Problems in comprehension of informed consent in rural and peri-urban Mali, West Africa. Clin Trials 2006, 3:306-313.

41. Oduro AR, Aborigo RA, Amugsi D, Anto F, Anyorigiya T, Atuguba F, Hodgson A, Koram KA: Understanding and retention of the informed consent process among parents in rural northern Ghana. BMC Med Ethics 2008, 9:12.

42. OnvomahaTindana P, Kass N, Akweongo P: The informed consent process in a rural African setting: a case study of the Kassena-Nankana district of Northern Ghana. IRB 2006, 28:1-6.

43. Molyneux CS, Peshu N, Marsh K: Understanding of informed consent in a low-income setting: three case studies from the Kenyan coast. Soc Sci Med 2004, 59:2547-2559.

44. Scarpelli AC, Ferreira E, Zarzar PMPA: Vulnerabilidadesocioeconômicaversus autonomia na pesquisa em saúde. Revista Bioética 2008, 15:298-307.

45. Guimarães MCS, Novaes SC: Autonomia reduzida e vulnerabilidade: liberdade de decisão, diferença e desigualdade. Bioética 1999, 7:1.

46. Rogers W, Ballantyne A: Populações especiais: vulnerabilidade e proteção. R Eletr De Com Infl Nov Saúde 2008, 2(sup 1):31-41.

47. Azevedo MA: Mulheres Espancadas - A Violência Denunciada. Rio de Janeiro: Editora Cortez; 1985. 
48. Council for International Organizations of Medical Sciences: International Ethical Guidelines for Biomedical Research involving Human Subjects; 2002. Available:http://www.cioms.ch/publications/layout_guide2002.pdf. Accessed 7 February 2013

49. World Medical Association: World Medical Association Declaration of Helsinki: Ethical Principles for Medical Research involving Human Subjects; 2008. Available: http://www.wma.net/en/30publications/10policies/b3/17c.pdf. Accessed 7 February 2013.

50. Weijer C, Crouch RA: Why should we include women and minorities in randomized controlled trials? J Clin Ethics 1999, 10:100-106.

51. Amorim MMM, Santos LC: Tratamento da vaginose bacteriana com gel vaginal de Aroeira (Schinus terebinthifolius Raddi): ensaio clínico randomizado. Rev Bras Ginecol Obstet 2003, 25:95-102.

52. Frank LL, Sorensen BE, Yasui $Y$, Tworoger SS, Schwartz RS, Ulrich CM, Irwin ML, Rudolph RE, Rajan KB, Stanczyk F, Bowen D, Weigle DS, Potter JD, McTiernan A: Effects of exercise on metabolic risk variables in overweight postmenopausal women: a randomized clinical trial. Obes Res 2005, 13:615-625.

53. Miller VA, Ittenbach RF, Harris D, Reynolds WW, Beauchamp TL, Luce MF, Nelson RM: The decision making control instrument to assess voluntary consent. Med Decis Making 2011, 5:730-741.

doi:10.1186/1471-2458-14-1156

Cite this article as: Lobato et al: Impact of gender on the decision to participate in a clinical trial: a cross-sectional study. BMC Public Health 2014 14:1156.

\section{Submit your next manuscript to BioMed Central and take full advantage of:}

- Convenient online submission

- Thorough peer review

- No space constraints or color figure charges

- Immediate publication on acceptance

- Inclusion in PubMed, CAS, Scopus and Google Scholar

- Research which is freely available for redistribution 